\title{
Laboratory and in situ assays of digital image analysis based protocols for biodeteriorated rock and mural paintings recording
}

\author{
M.A. Rogerio-Candelera, V. Jurado, L. Laiz, C. Saiz-Jimenez
}

Instituto de Recursos Naturales y Agrobiología de Sevilla, Consejo Superior de Investigaciones Científicas. Avda. Reina Mercedes, 10; 41012 Sevilla

\begin{abstract}
Rock art paintings, and in general mural paintings, are one of the many elements of cultural heritage complex systems. As the different elements of a system have diverse spatial positions, spatial recording allows understanding their interactions. Thus, a useful approach to mural paintings recording is to understand it as a microcartography issue, managing each element of the system as a cartographic coverage.

The approach implemented emphasizes the utilization of data obtained by remote sensing techniques for extracting different kinds of information susceptible of being analysed, classified and plotted in a differentiate way by means of the possibility of reducing redundant data by Principal Component Analysis (PCA) and the elaboration of false-colour images from uncorrelated bands.

A laboratory model was prepared in order to simulate biodeterioration of rock art. The samples were photographically recorded thereafter under different lighting conditions, and PCA applied to the resulting images. False-colour images obtained by combining Principal Component bands allowed us to reach results similar to those of an unsupervised classification. The method has been applied to Roman mural paintings from one of the tombs of Carmona Necropolis, obtaining good results.
\end{abstract}

Keywords: rock art; digital image analysis; biodeterioration; mural paintings

\section{INTRODUCTION}

In situ cultural remains, as rock art paintings and, in general, mural paintings constitute one of the many components of complex natural systems in which they act as abiotic elements. The complexity of these systems includes of a great amount of elements, mainly of abiotic, but also biotic nature. The study of the system should attend to the ensemble because the 
structure itself and also the synergies generated are responsible for its stability. These determine a dynamic equilibrium maintained between homeostatic and entropic tendencies. Spatial distribution of its diverse elements is particularly important in the description of the system because every natural system takes up a place in space and the interaction between its elements is a function of their relative positions (Margalef 1982). For this reason, conservative recording should not elude the different elements integrating the system, nor also their spatial dimension, which constitutes an extent of their interaction. Thus, mural paintings recording, especially for those affected by biodeterioration processes can be treated as a microcartography issue, in which every element of the system can be understood as a distinctive cartographic coverage, and, due to this reason, appropriate for mapping (RogerioCandelera 2008). Recording products can, thus, be understood as thematic maps, in which every element of the system become a class.

Basically, there are two possible ways to elaborate cartography: one, to emphasize traditional topographical procedures in order to create a base map in which represent the thematic information that the coverages offer; and second, to use data from remote sensors in order to establish a classification, interpreted a posteriori, if unsupervised, or a priori, based on a series of training pixels, if supervised, used when we previously know enough about the system we are mapping.

The implementation of classification strategies of digital images is a common procedure in remote sensing, especially in applications related to satellite-based mineral survey (e.g. Taylor 2000, Zhang et al. 2007). As the behaviour of the different materials respect to different wavelengths is distinctive of their compositions, fitted classifications of the different coverages included in satellite imagery can be performed by means of the use of a set of bands, representing data from different wavelength intervals. Digital classification of standard RGB images produce poor results in many cases, especially when the images are highly visually correlated, i.e. when the pixel values in the red, blue and green bands are very close, with the effect of producing similar colours.

In rock art recording research field, the use of image analysis strategies has been limited in some cases to the application of digital filters and binarisation by simple thresholding algorithms (Clogg et al. 2000) or, more commonly, the enhancement by contrast stretching and the elaboration of the "digital tracings", selecting and pasting in different layers of Photoshop ${ }^{\circledR}$ or similar software packages (Lopez Montalvo and Domingo Sanz 2009). These methods, though are not invasive, have demonstrated little resolution when the correlation of the pixel values in the different bands is high. Other authors, on the contrary, employ 
Photoshop ${ }^{\circledR}$ to enhance the rock art motifs by means of linear histogram stretch of RGB, CMYK or Lab (CIE $L^{*} a^{*} b^{*}$ ) colour mode images (Mark and Billo 2002). Several works have shown the usefulness of the utilization of Principal Component Analysis for rock art images enhancement (Vicent García et al. 1996, Mark and Billo 2006), the possibilities offered by the adoption of a mixed supervised and unsupervised classification strategy (Buchner et al. 2000), or the interest of multispectral recording (Robinson and Ware 2002). In the last years, DStretch, a software applet for ImageJ developed by Jon Harman is being widely used for digital enhancement of rock art images (Harman 2008). An interesting application of DStretch for the study of superimpositions has been recently published by Gunn et al. (2010). Among its advantages is the automatism for the enhancement of most rock art motifs, although it does not allow multispectral work as is limited to three-band image cubes.

The methodological approach followed in this work takes into account these pitfalls and propose the use of digital image decorrelation techniques, as Principal Component Analysis, as a previous treatment to improve the visualization of different coverages present in digital images of rock and mural paintings, followed of the composition of false colour images using the minority Principal Components bands in order to facilitate the application of classification algorithms, or the elaboration of composite image cubes from PC bands from images obtained with different lighting conditions to map the different elements present in the images.

\section{MATERIALS AND METHODS}

Our approach is based on the possibility of reducing redundant data that Principal Component Analysis (PCA) allows to reach on highly correlated images, and the composing of false-colour images from the bands obtained by this statistical treatment of images.

Thus, we built a laboratory simulation model of rock paintings biodeterioration, by means of samples of two lithotypes, chosen by their different granulometry, colour and porosity; sterile polycarbonate boxes and sterile bentonite to maintain humidity.

\subsection{Samples}

\subsubsection{Villamayor sandstone}

Feldspatic sandstone-arkose. Mainly composed of quartz (40-70\%), with feldspars (10$30 \%$ ), and $10-20 \%$ of mica and clay matrix. This stone is originary from several quarries surrounding Villamayor (Salamanca, Spain), from a lithofacies of the Cabrerizos Sandstone 
formation, with riverine origin and dated in higher Palaeogene. The lithotype shows grain sizes from fine to medium, brittle by touch and white-yellowish to brown-reddish colorations due to the content on Fe oxides (García de los Ríos and Báez 2001).

\subsubsection{Campaspero white stone}

Dismicrite (Fossiliferous micritic limestone). It comes from several quarries from the South of Campaspero (Valladolid, Spain). Of Turolian age, its sedimentary origin lies in marginal areas of very slight carbonated lacustrine systems, subjected to drastic changes in the water level. It is a compact rock, greyish white, vuggy, patinated in a slightly darkening to pale cream colour (García de los Ríos and Báez 2001).

\subsubsection{Rock paintings simulation}

Rock samples were cut in pieces of approximately $4 \times 4 \times 0.5 \mathrm{~cm}$. Over them, simple and easy-recognizable motifs were paint brush-painted: triangles on Villamayor sandstone, and squares on Campaspero limestone (Figure 1).

The designs were painted using haematite ground in an agate mortar as pigment and olive oil as a binder. The pigment was chosen to try to reproduce one of the most utilized materials for elaborating red-coloured rock paintings. Thus, haematite has been detected as the main component in Palaeolithic paintings from France (Menu and Walter 1992, Vignaud et al. 2006) and Spain (Hoyos et al. 1999, Garate et al. 2004), and also in post-Palaeolithic paintings from the North (Hameau et al. 2001) and South of the Pyrenees (Garate et al. 2004, Hoyos et al. 1997, 1998). The nature of the binders in rock art is, nevertheless, not clear, mainly due to the difficulties for the identification of biochemical markers in so small samples as those usually obtained from cultural assets. Some authors have suggested the utilization of fats, from oil (Pepe et al. 1991), or even cow butter (Bello and Carrera 1997). Some others consider the absence of binder or the mix of the pigment with water (Múzquiz 1988), though these conclusions have been established through experimental procedures but without analysing rock art samples. In this work, we chose to mix the pigment with olive oil, due to the need of mixing the pigment with some fatty substance in order to warranty the adherence of the paint to the stone, as experimentally detected by Mas Cornellà (2005).

\subsubsection{Accelerated biodeterioration experiment}

Tests have been performed in triplicates, calling V1, V2 and V3 to samples corresponding to designs in Villamayor sandstone, and $\mathrm{C} 1, \mathrm{C} 2$ and $\mathrm{C} 3$ to those corresponding to 
Campaspero limestone. Samples were placed inside sterile $6.5 \times 6.5 \times 10 \mathrm{~cm}$ polycarbonate boxes, over a bed of sterile bentonite in order to maintain humidity and favour the development of a phototrophic biofilm on the painted surfaces (Figure 2).

In order to accelerate the biological colonization, the stones were wetted with BG11 culture medium (Ariño 1996) especially designed for the cultivation of cyanobacteria, thereafter inoculated with a suspension of active algae and cyanobacteria from natural samples. Phototrophic communities inoculated were identified by molecular methods in a previous work (Laiz et al. 2006), showing that most of them were microalgae belonging to the Chlorophyta Division, as Chlorella, and other less abundant genera as Stichococcus and Trebouxia. Inoculated stones were incubated for thirty days at $20^{\circ} \mathrm{C}$ with continuous lighting.

\subsubsection{Recording}

After the incubation period, the samples were photographically recorded with sunlight and UV lighting ( $\lambda=312 \mathrm{~nm}$ ) with a standard digital photographic camera (Nikon E5200), with a resolution of $2592 \times 1944$ pixels, $8 \mathrm{~mm}$ focal length, lens opening F/2.8 and $1 \mathrm{~s}$ exposure time for sunlight photographs and $0.25 \mathrm{~s}$ for UV lighting photographs. UV lighting was interesting for the detection of the possible fluorescence of constituent materials, as some carbonates, and subsequent mapping of these elements (Rogerio-Candelera 2010), as well as to induce fluorescence to biological elements (Meyer et al. 2003, Bélanger et al. 2008). RGB standard photographs with UV lighting were made in a dark room. The results were two series of three-band images, saved as JEPG. Figure 3 summarizes the utilized protocol.

\subsection{Digital Image Analysis}

The obtained images were processed utilizing HyperCube software package (US Army Topographic Engineering Centre, Alexandria, Virginia, USA), which allowed us the creation of image cube composites from photographs with different lighting conditions, elaboration of false-colour images from cube composites, Principal Component Analysis from these falsecolour images, and again false-colour images from PCA bands. PCA is a powerful statistical technique for multivariate analysis, which allows the remapping of the pixel values (DN) of the different bands of the image in a new reference system of uncorrelated axes, thus distributing decreasingly the variance represented in each band. Typically, the Principal Components of a digital image are obtained by means of the expression: 


$$
P C_{j}=\sum_{i=1, p} a_{i j} D N_{i}+R_{j}
$$

where $P C_{j}$ represent the pixel value corresponding to Principal Component $j, a_{i, j}$ is the coefficient applied to the pixel value of the band $i$ in order to generate the component $j$ and $R_{j}$ a constant introduced in each component in order to avoid negative values.

As a previous step, little adjusts in the image geometry were performed by means of Adobe PhotoshopCS $^{\circledR}$ software, in order to make them comparable. This software has shown potentialities for digital photorestitution of images and elaboration of ortophotomaps from these (Mark and Billo 1999, Rogerio-Candelera et al. 2008). Digital restitution of images constitutes a task of difficult resolution when only single images are available. Abundant bibliography is written around this problem, proposing several geometrical options (Schuhr and Kanngieser 1999, 2001, 2003). In our case, the normal position of the photographic camera respect to the painted areas, and the fact that the recorded surfaces were considerably flat, made unnecessary the use of digital photogrammetric methods, being enough the Photoshop $^{\circledR}$ solution by means of the commands "distort". Figure 4 shows the steps followed in this work to develop our image analysis approach.

\section{RESULTS AND DISCUSSION}

PCA application to false-colour images from cube composites allowed to obtain three different bands for every original image, which represented decreasing percentages of information in each one of them (Martínez Arias 1999), totally uncorrelated between them as they are represented in a new reference system of uncorrelated axes (Gillespie et al. 1986). The combination of bands from images with different lighting conditions made possible the elaboration of easily interpretable false-colour images, in which different coverages can be detected. These results are comparable to those of an ideal unsupervised image classification (Figure 5), i.e. allowed us to obtain different colours to represent different realities enclosed in the original images without a previous selection of the categories, just in the same way that an unsupervised digital classification algorithm works. Of special interest is the fact that false colour images elaborated by PC bands of standard RGB digital images are also interpretable as digital classifications. Unsupervised digital classifications consist in the assignation of every pixel of a digital image to a concrete category, i.e. to a spectral class, as they are based solely on the natural groupings in the image values (Lillesand and Kiefer, 2000). From this 
point of view, these methods allow the separation of the different elements included in the images by their spectral behaviours. The decorrelation approach used in this work points to the same kind of separation, as the use of the minority PC bands allows detecting elements "hidden" and their subsequent mapping.

The accuracy of a digital classification clearly depends on the sensitivity of the sensor, i.e., the broader the spectral sensitivity, the greater the accuracy, as diverse elements can have diverse spectral signatures that can be similar in the recorded wavelength interval. As Figure 6 shows, the results of a K-means unsupervised classification algorithm of a sunlight RGB image can be poor if only the information of the three bands of the visible wavelength interval are available.

As Figure 5 shows, the contribution of UV fluorescent bands is interesting for the definition and mapping of the biological coverage, but does not improve relevantly the visualisation of the painting obtained by the PC3 band.

The next goal of the research was to contrast if our results could be extrapolated to a real target, i.e. if the simple treatment of the images by PCA, and the composition of false-colour images helped to distinguish the different coverages (both of biotic and abiotic nature) present in biodeteriorated cultural assets, and in particular to distinguish the painted areas from the background, allowing the differentiation of paint from other elements product of biological activity.

For that purpose, one of the tombs of the Roman Necropolis at Carmona (Sevilla, Spain), was the selected place for experimentation. The Tomb of the three doorways (Figure 7) was one of the tombs excavated by G.E. Bonsor in the 1880's (Rada y Delgado 1888), experimenting since this change in its environmental conditions diverse deterioration processes including concretions over the painted stucco and the development of a phototrophic biofilm on the rock surface. The area selected for experimental recording includes green painted stucco and shows several deterioration processes, with the effect of masking the motifs.

Images from the study area were selected in order to apply the image analysis protocol defined above. Figure 8 graphically describes the results reached, delimiting the spatial extension of the diverse elements integrating the system, and also allowing the observation of the painting remains in the stucco. The utilization of false-colour images elaborated with the minority PC bands (those corresponding to the 2nd and 3rd Principal Components) have demonstrated to be a good approach for the detection of the elements, showing, for instance, the amount of stucco remains still in situ but fissured and sometimes covered by concretions. 
The painting remains can also be best observed using this approach due that they are quite covered by this efflorescences and the third Principal Component maps the residual uncorrelated information (Martinez Arias 1999), not shown in Principal Components 1 and 2. A false-colour image integrated by the 3 bands obtained by PCA is shown to illustrate its ability to map the most external shapes, as the concretions covering the paintings.

The possibilities opened by the mathematical treatment of digital images, both for archaeological research and design of conservation strategies, are wide as they allow obtaining qualitative and quantitative data of interest for archaeology and for cultural heritage conservation. Thus, the possibility of obtaining a fitted shape of the painted motifs allows minimizing the subjectivity implicit in most recording methods. If it is true that the elaboration of a tracing of a rock art motif is a task that implies the deciphering and interpretation (Lorblanchet 1995) it isn't less true that the interpretation process indeed may imply an important amount of subjectivity, which may put at risk the validity of the whole process of observation-interpretation (Montero Ruiz et al. 1998). The utilization of digital images, understood as data matrices with a correlate in the real reflectance of the materials, allows establishing objective criteria, as they are based in physicochemical parameters as the composition, for a fitted tracing also avoiding confusion between artefacts and natural shapes. The complementation of the image analysis strategy followed in this work (decorrelation by Principal Component Analysis and elaboration of false-colour images) with the digital classification of the pixel values of the obtained images seems to be a promising way in the field of non-invasive recording, as fitted tracings should be obtained without the need of contact, and, at the same time important information, as different paint compositions, (Rogerio-Candelera et al. 2009) can be graphically detected, relevantly contributing to improve the interpretation of the panels as cumulative or simultaneous.

\section{CONCLUSIONS}

False-colour images elaborated from bands originated by PCA allow discriminating different shapes corresponding to the different elements of the system. The results are similar to those ideally obtained by means of the application of unsupervised classification algorithms to the original image.

Minority Principal Components (PC2 and PC3) are the most suitable for a precision mapping, due to the reduction of noise that they offer in comparison with the 1st PC, which includes almost all the information registered in the original image. Minority PC reflect 
information hidden by the majority one, which is of particular importance for the mapping of complex systems such as mural or rock paintings.

The possibility of establishing, by means of non-invasive methods, the spatial component of biodeterioration phenomena is basic for their temporal monitoring, in order to elaborate models allowing the adoption of a suitable conservation strategy.

\section{ACKNOWLEDGEMENTS}

Dr. Robert Mark is acknowledged for his useful suggestions. The three anonymous reviewers of the paper are also acknowledged for enriching it with their constructive suggestions. Project CGL2010-17183, Spanish Ministry of Science and Innovation, is acknowledged for funding. Consejería de Cultura, Junta de Andalucía is also acknowledged for the facilities. This is a CSD2007-00058 paper.

\section{REFERENCES}

Ariño, X., 1996. Estudio de la colonización, distribución e interacción de líquenes, algas y cianobacterias con los materiales pétreos de los conjuntos arqueológicos de Baelo Claudia y Carmona. PhD. Thesis. University of Barcelona.

Bélanger, M.-C., Roger, J.-M., Cartolaro, P., Viau, A.A., Bellon-Maurel, V., 2008. Detection of powdery mildew in grapevine using remotely sensed UV-induced fluorescence. International Journal of Remote Sensing 29(6): 1707-1724.

Bello, J.M., Carrera, F., 1997. Las pinturas del monumento megalítico de Dombate: estilo, técnica, composición, in: Rodríguez Casal, A.A. (Ed.), O Neolítico Atlántico e as orixes do Megalitismo. Actas do Coloquio Internacional (Santiago de Compostela, 1-6 de Abril de 1996). Universidad de Santiago de Compostela, Santiago de Compostela, pp. 819-828.

Bonsor, G.E., 1931. The archaeological sketch-book of the Roman necropolis at Carmona. The Hispanic Society of America, New York.

Buchner, A.P., Hathout, S., Russell, B., 2000. Digital enhancement of a prehistoric rock painting from Hazlet, Saskatchewan, in: Whitehead, P., Loendorf, L. (Eds.), 1999 IRAC Proceedings, Volume 1. American Rock Art Research Association, Phoenix (AZ), pp. 19-24. 
Clogg, P., Diaz-Andreu, M., Larkman, B., 2000. Digital image processing and the recording of rock art. Journal of Archaeological Science 27: 837-843.

Garate, D., Laval, E., Menu, M., 2004. Étude de la matière colorante de la grotte d'Arenaza (Galdames, Pays Basque, Espagne). L’Anthropologie 108: 251-289.

García de los Ríos, J.I., Báez, J.M., 2001. La piedra en Castilla y León. Junta de Castilla y León, Valladolid.

Gillespie, A.R., Kahle, A.B., Walker, R.E., 1986. Color enhancement of highly correlated images. I. Decorrelation and HSI contrast stretches. Remote Sensing of Environment 20: 209-235.

Gunn, R.G., Ogleby, C.L., Lee, D., Whear, R.L., 2010. A method to visually rationalise superimposed pigment motifs. Rock Art Research 27(2): 131-136.

Hameau, P., Cruz, V., Laval, E., Menu, M., Vignaud, C., 2001. Analyse de la peinture de quelques sites postglaciaires du Sud-Est de la France. L'Anthropologie 105: 611-626.

Harman, J., 2008. Using decorrelation strecht to enhance rock art images, [online], http://www.dstretch.com/AlgorithmDescription.html, [accession 07/12/2010].

Hoyos, M., Cañaveras, J.C., Sánchez-Moral, S., Sanz-Rubio, E., Blanco-Varela, M.T., Puertas, F., Palomo, A., Saiz-Jimenez, C., Ariño, X., 1997. Estudio de los procesos de alteración de las rocas y pinturas de los abrigos de Atlanterra y Alemanes (Cadiz) y de los Letreros (Almeria). Report for Consejería de Cultura, Junta de Andalucía.

Hoyos, M., Cañaveras, J.C., Sánchez-Moral, S., Sanz-Rubio, E., Blanco-Varela, M.T., Puertas, F., Palomo, A., Saiz-Jimenez, C., Ariño, X., 1998. Estudio de los procesos de alteración de las rocas y pinturas de los abrigos de Cueva de la Graja y Cueva del Encajero. Report for Consejería de Cultura, Junta de Andalucía.

Hoyos, M., Cañaveras, J.C., Sánchez-Moral, S., Sanz-Rubio, E., Blanco-Varela, M.T., Puertas, F., Palomo, A., Saiz-Jimenez, C., Ariño, X. 1999. Estudio de los procesos de alteración de las rocas y pinturas de las cuevas de Los Murciélagos (Zuheros, Córdoba) y Doña Trinidad (Ardales, Málaga). Report for Consejería de Cultura, Junta de Andalucía.

Laiz, L., Gonzalez, J.M., Portillo, M.C., Gazulla, M.F., Sanchez, E., Saiz-Jimenez, C., 2006. Microbial assessment of the biological colonization on roofing tiles, in: Fort, R., Alvarez de Buergo, M., Gomez-Heras, M., Vazquez-Calvo, C. (Eds.), Heritage, Weathering and Conservation. Taylor \& Francis, London, pp. 349-353.

Lillesand, T.M., Kiefer, R.W., 2000. Remote Sensing and Image Interpretation. Fourth Edition. John Wiley and Sons, New York. 
López-Montalvo, E., Domingo Sanz, I., 2009. Nuevas técnicas aplicadas a la documentación gráfica del arte levantino: valoración crítica del método tras una década de experimentación, in: López Mira, J.A., Martínez Valle, R., Matamoros de Villa, C. (Eds.), El Arte Rupestre del Arco Mediterráneo de la Península Ibérica. 10 años en la lista del Patrimonio Mundial de la Unesco. Actas del IV Congreso. Valencia, 3, 4 y 5 de diciembre de 2008. Generalitat Valenciana, Valencia, pp. 295-302.

Lorblanchet, M., 1995. Les grottes ornées de la Préhistoire. Errance, Paris.

Margalef, R., 1982. Ecología. Omega, Barcelona.

Mark, R., Billo, E., 1999. A stitch in time: Digital panoramas and mosaics, in: Freers, S.M. (Ed.), American Indian Rock Art. American Rock Art Research Association, Ridgecrest (CA), 25: 155-168.

Mark, R., Billo, E., 2002. Application of digital image enhancement in rock art recording, in: Woody, A. (Ed.), American Indian Rock Art. American Rock Art Research Association, Ridgecrest (CA), 28: 121-128.

Mark, R., Billo, E., 2006. Computer-assisted photographic documentation of rock art. Coalition 11: 10-14.

Martínez Arias, R., 1999. El análisis multivariante en la investigación científica. La Muralla/Hespérides, Madrid.

Mas Cornellà, M., 2005. La cueva del Tajo de las Figuras. UNED, Madrid.

Menu, M., Walter, P., 1992. Prehistoric cave painting PIXE analysis for the identification of paint “pots". Nuclear Instruments and Methods in Physics Research B 64: 547-552.

Meyer, S., Cartelat, A., Moya, I., Cerovic, Z.G., 2003. UV-induced blue-green and far-red fluorescence along wheat leaves: a potential signature of leaf ageing. Journal of Experimental Botany 54(383): 757-769.

Múzquiz, M., 1998. Análisis artístico de las pinturas rupestres del Gran Techo de la Cueva de Altamira. Materiales y técnicas. PhD. Thesis. Universidad Complutense de Madrid.

Pepe, C., Clottes, J., Menu, M., Walter, P., 1991. Le liant des peintures paléolithiques ariégeoises. Comptes Rendus de l'Académie des Sciences de Paris, Série 2 312: 929934.

Rada y Delgado, J.D. de la, 1888. Necrópolis de Carmona: memoria escrita en virtud de acuerdo de las Reales Academias de la Historia y de Bellas Artes de San Fernando. Madrid. 1885. Separata de Memorias de la Real Academia de la Historia, Tomo XI, Madrid.

Robinson, E.J., Ware, G.A., 2002. Multi-spectral imaging of La Casa de las Golondrinas rock 
paintings, [online], <http://www.famsi.org/cgi-bin/print_friendly.pl?file=99052>, [accession 07/12/2010].

Rogerio-Candelera, M.A., 2008. Una propuesta no invasiva para la documentación integral del arte rupestre. CSIC, Sevilla.

Rogerio-Candelera, M.A., 2010. El análisis de imagen como herramienta de investigación no invasiva de cuevas con arte rupestre, in: Durán, J.J., Carrasco, F. (Eds.), Cuevas: Patrimonio, Naturaleza, Cultura y Turismo. ACTE, Madrid , pp. 203-216.

Rogerio-Candelera, M.A., Laiz, L., Gonzalez, J.M., Saiz-Jimenez, C., 2008. Monitorización del crecimiento microbiano en una tumba romana mediante técnicas de teledetección, in: Rovira Llorens, S., García-Heras, M., Gener Moret, M., Montero Ruiz, I. (Eds.), Actas del VII Congreso Ibérico de Arqueometría. Instituto de Historia, Madrid, pp. 593600 .

Rogerio-Candelera, M.A., Vanhaecke, F., Resano, M., Marzo, P., Porca, E., Alloza Izquierdo, R., Sáiz-Jiménez, C., 2009. Combinación de análisis de imagen y técnicas analíticas para la distinción de diferentes fases en un panel rupestre (La Coquinera II, Obón, Teruel), in: López Mira, J.A., Martínez Valle, R., Matamoros de Villa, C. (Eds.), El Arte Rupestre del Arco Mediterráneo de la Península Ibérica. 10 años en la lista del Patrimonio Mundial de la Unesco. Actas del IV Congreso. Valencia, 3, 4 y 5 de diciembre de 2008. Generalitat Valenciana, Valencia, pp. 327-334.

Schuhr, W., Kanngieser, E., 1999. Single images in conservation, in: XVII CIPA International Symposium. Olinda, Brasil, 3-6 Octubre 1999, [online], $<$ http://cipa.icomos.org/fileadmin/papers/olinda/99c803.pdf $>$, [accession 10/10/2006].

Schuhr, W., Kanngieser, E., 2001. Modern methods for using single images in conservation, in: XVIII CIPA International Symposium. Potsdam, Germany, [online], $<$ http//cipa.icomos.org/fileadmin/papers/potsdam/2001-13-ws01.pdf $>, \quad$ [accession $30 / 10 / 2006]$

Schuhr, W., Kanngieser, E., 2003. New perspectives for single images in conservation, in: XIX CIPA International Symposium "New perspectives to save Cultural Heritage", 30 Sep-04 2003. Act Antalya, Turkey, [online], $<$ http://cipa.icomos.org/fileadmin/papers/antalya/62.pdf $>$, [accesion 28/10/2006].

Taylor, G.R., 2000. Mineral and lithology mapping of drill core pulps using visible and infrared spectrometry. Natural Resources Research 9: 257-268. 
Vicent García, J.M., Montero Ruíz, I., Rodríguez Alcalde, A.L., Martínez Navarrete, M.I., Chapa Brunet, T., 1996. Aplicación de la imagen multiespectral al estudio y conservación del arte rupestre postpaleolítico. Trabajos de Prehistoria 53: 19-35.

Vignaud, C., Salomon, H., Chalmin, E., Geneste, J-M., Menu, M., 2006. Le groupe des «bisons adossés» de Lascaux. Étude de la technique de l'artiste par analyse des pigments. L'Anthropologie 110: 482-499.

Zhang, X., Pazner, M., Duke, N., 2007. Lithologic and mineral information extraction for gold exploration using ASTER data in the south Chocolate Mountains (California). ISPRS Journal of Photogrammetry \& Remote Sensing 62: 271-282. 


\section{$\underline{\text { Figure Captions }}$}

Figure 1. Lithotypes utilized in the experiment. Upper line: Villamayor sandstone. Lower line: Campaspero limestone.

Figure 2. Laboratory model for the accelerated biological colonization assay.

Figure 3. Scheme of the protocol for sample accelerated ageing utilized in this work.

Figure 4. Image analysis protocol for the detection of different shapes.

Figure 5. Digital images of sample V2 after accelerated biodeterioration. (A) Sunlight image. (B) UV lighting image. (C) PC3 band of the sunlight image showing clearly the remains of colonised and uncolonised painting. (D) False colour image elaborated from the three PC bands of sun lighting image, allowing differentiating several coverages: green, uncolonised paint; magenta, fungal colonisation; blue, phototrophic colonisation. (E) False colour image elaborated from PC1, PC3 and UV lighting PC3 bands. (F), False colour image elaborated from PC3, PC2 and UV lighting PC2 bands.

Figure 6. Classified sunlight image of V2 sample by an unsupervised K-means algorithm (20 iterations, 4 classes).

Figure 7. Tomb of the three doorways at the Roman Necropolis of Carmona. (A) Plan of the tomb, after Bonsor (1931). (B) Sampling area.

Figure 8. Tomb of the three doorways. (A) Original RGB image. (B) False-colour image (PC1, PC2, PC3). Classes: [1] concretions, [2] green Roman paint, [3] stucco, [4] phototrophic biofilm. (C) False-colour image (PC3, PC2, PC2). Classes: [1] green Roman paint, [2] phototrophic biofilm, [3] stucco, [4] concretions. 
Click here to download high resolution image
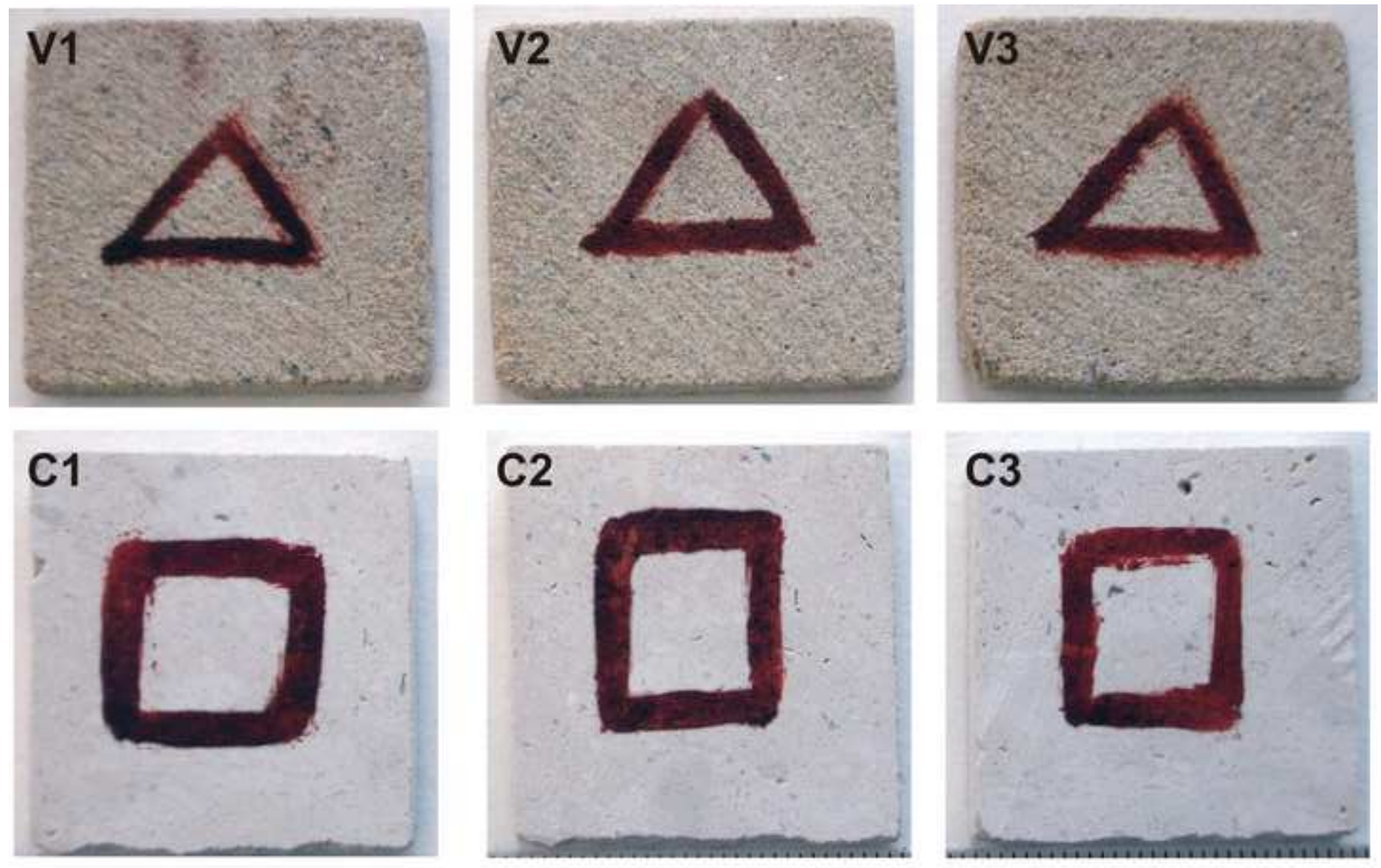

$1 \mathrm{~cm}$

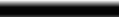


Figure
Click here to download high resolution image

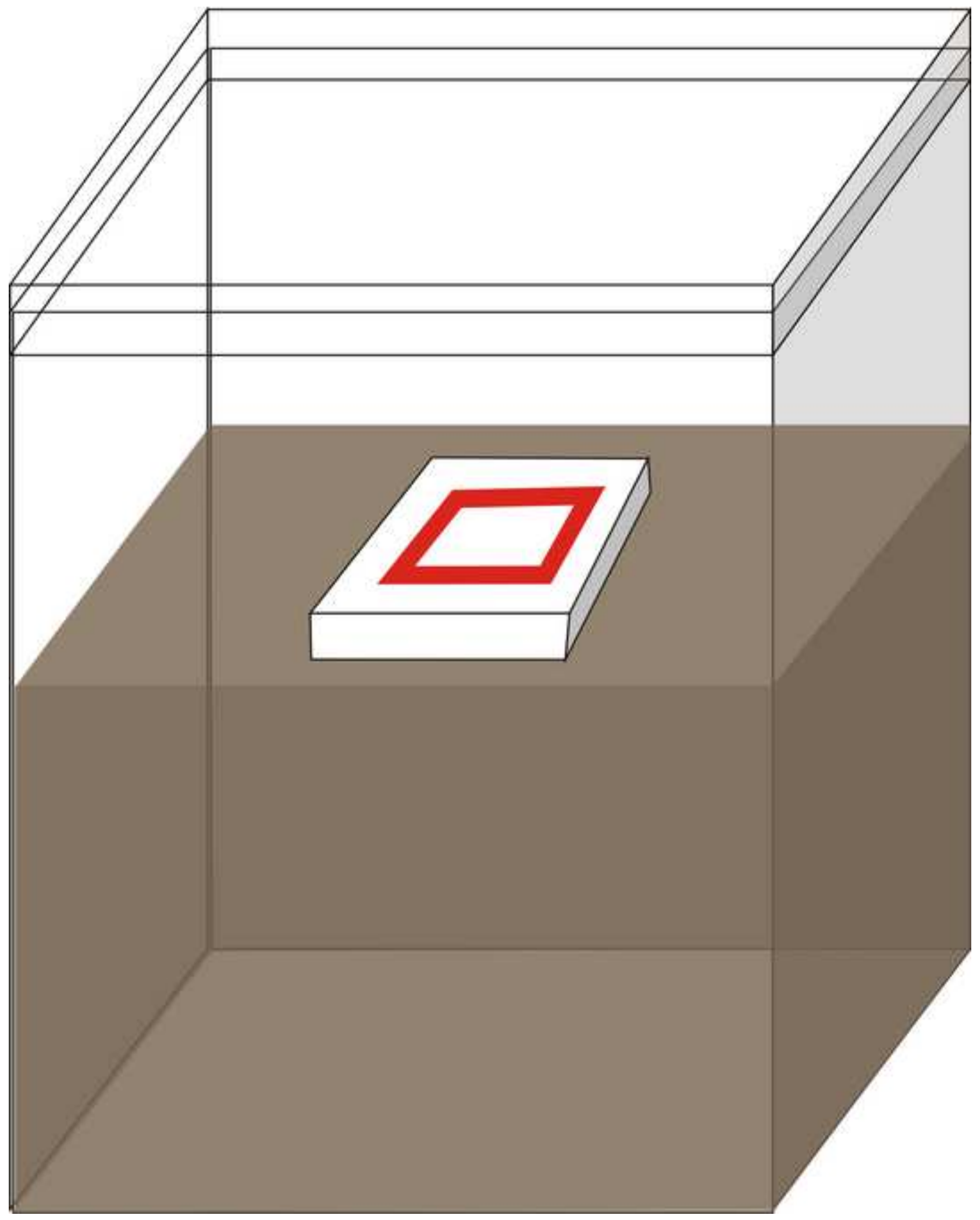


Figure
Click here to download high resolution image
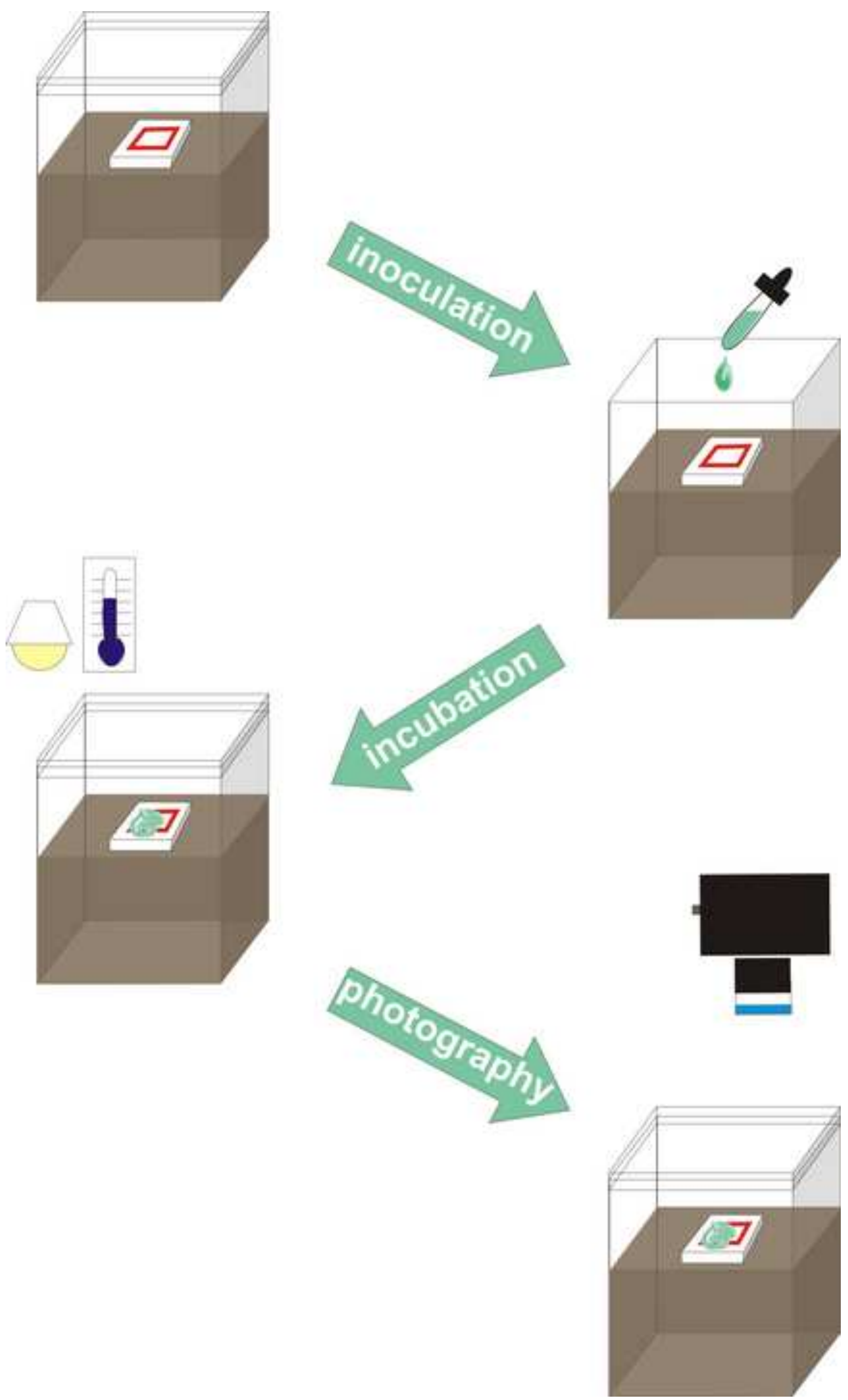
Click here to download high resolution image
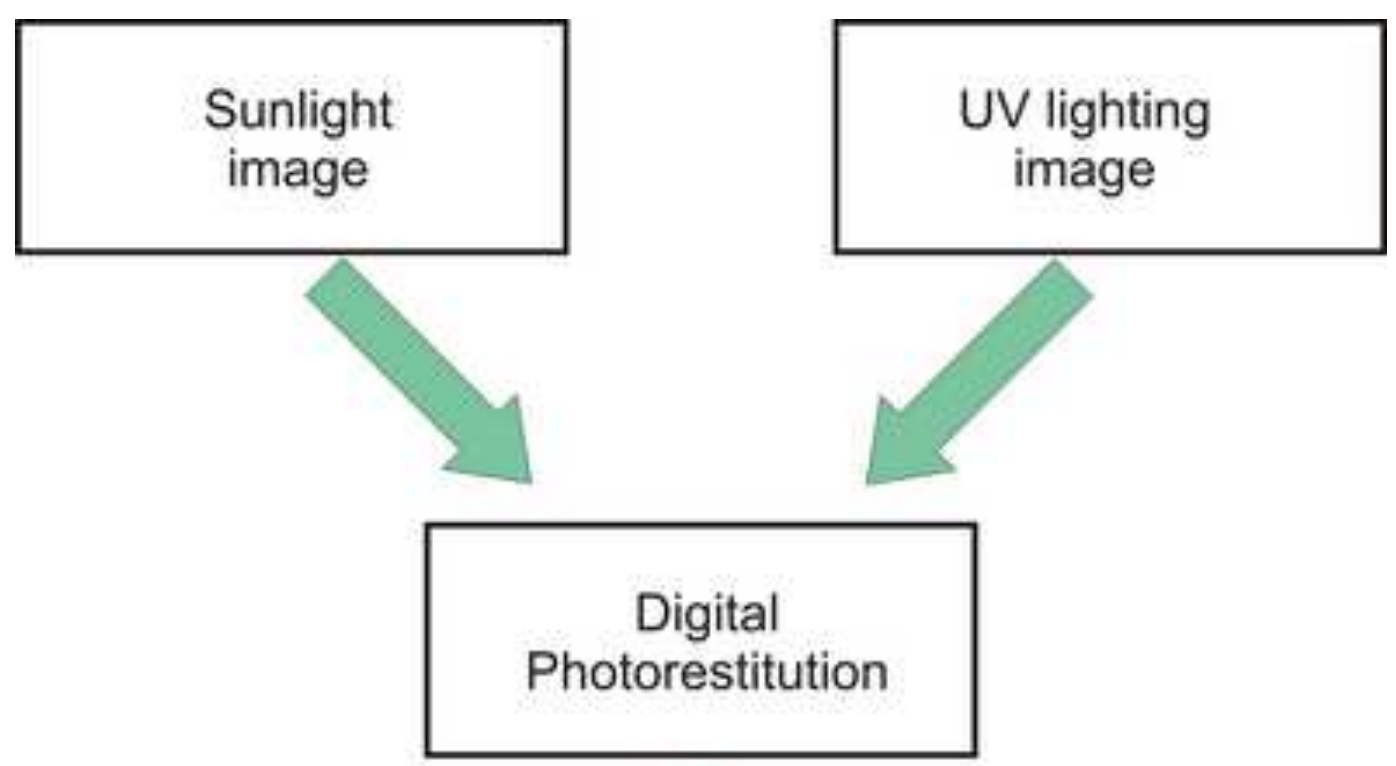

Image cube composite
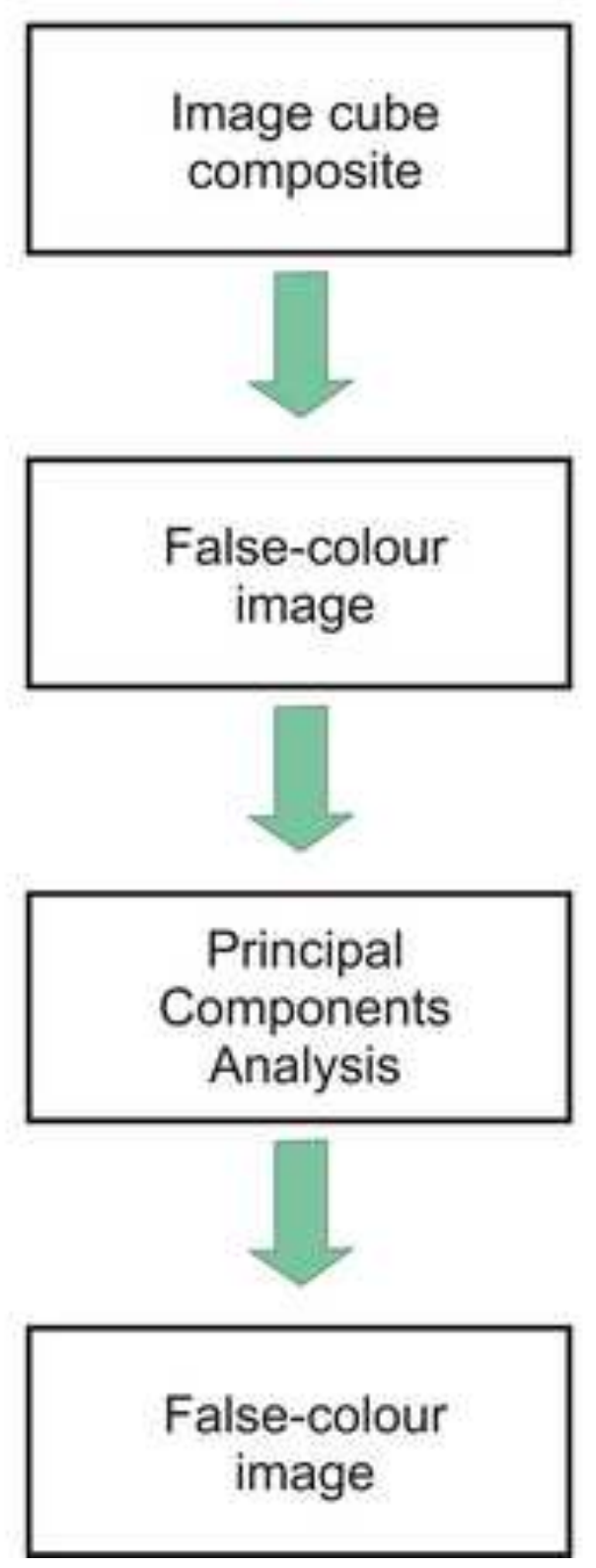

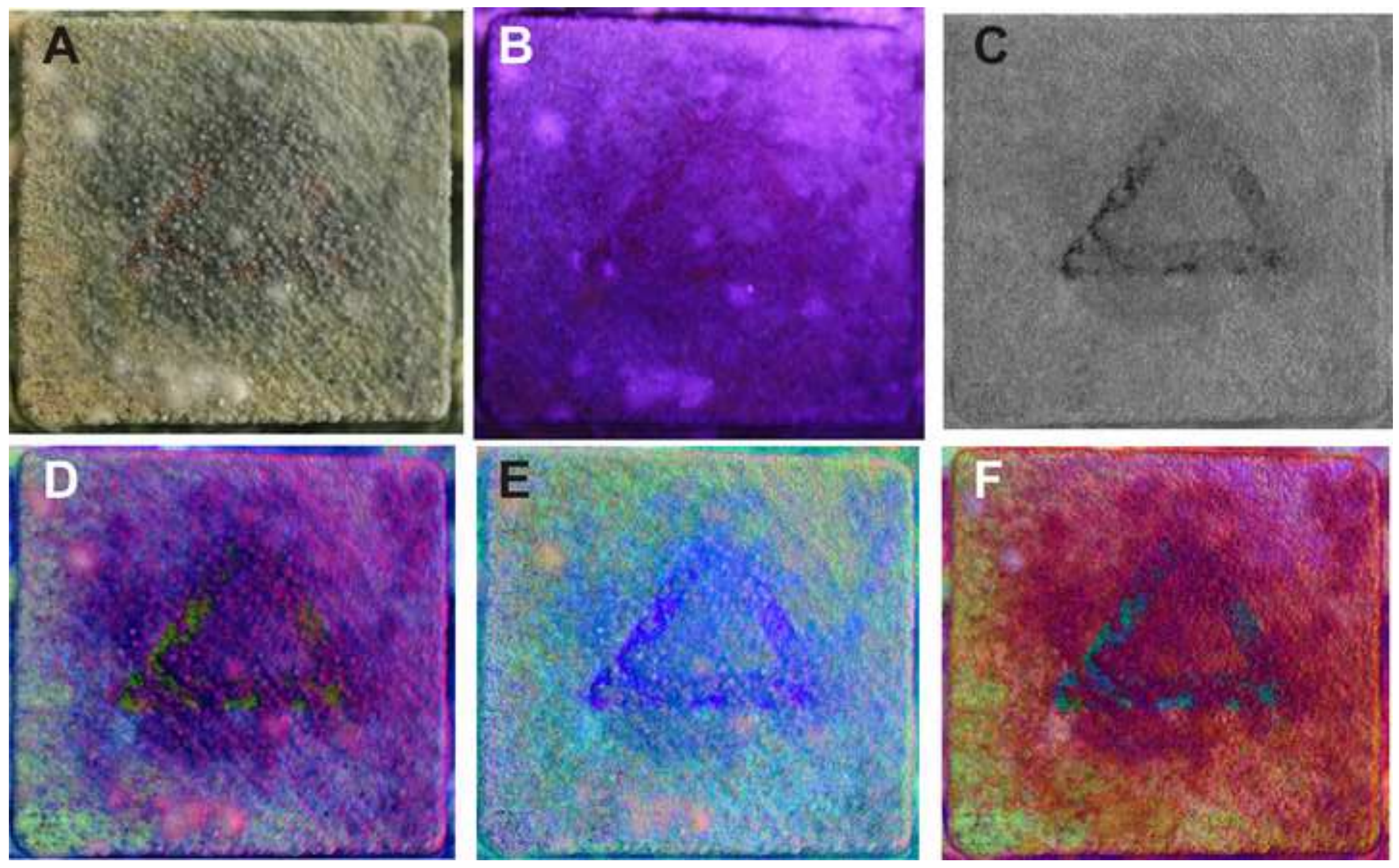

Click here to download high resolution image 
Click here to download high resolution image

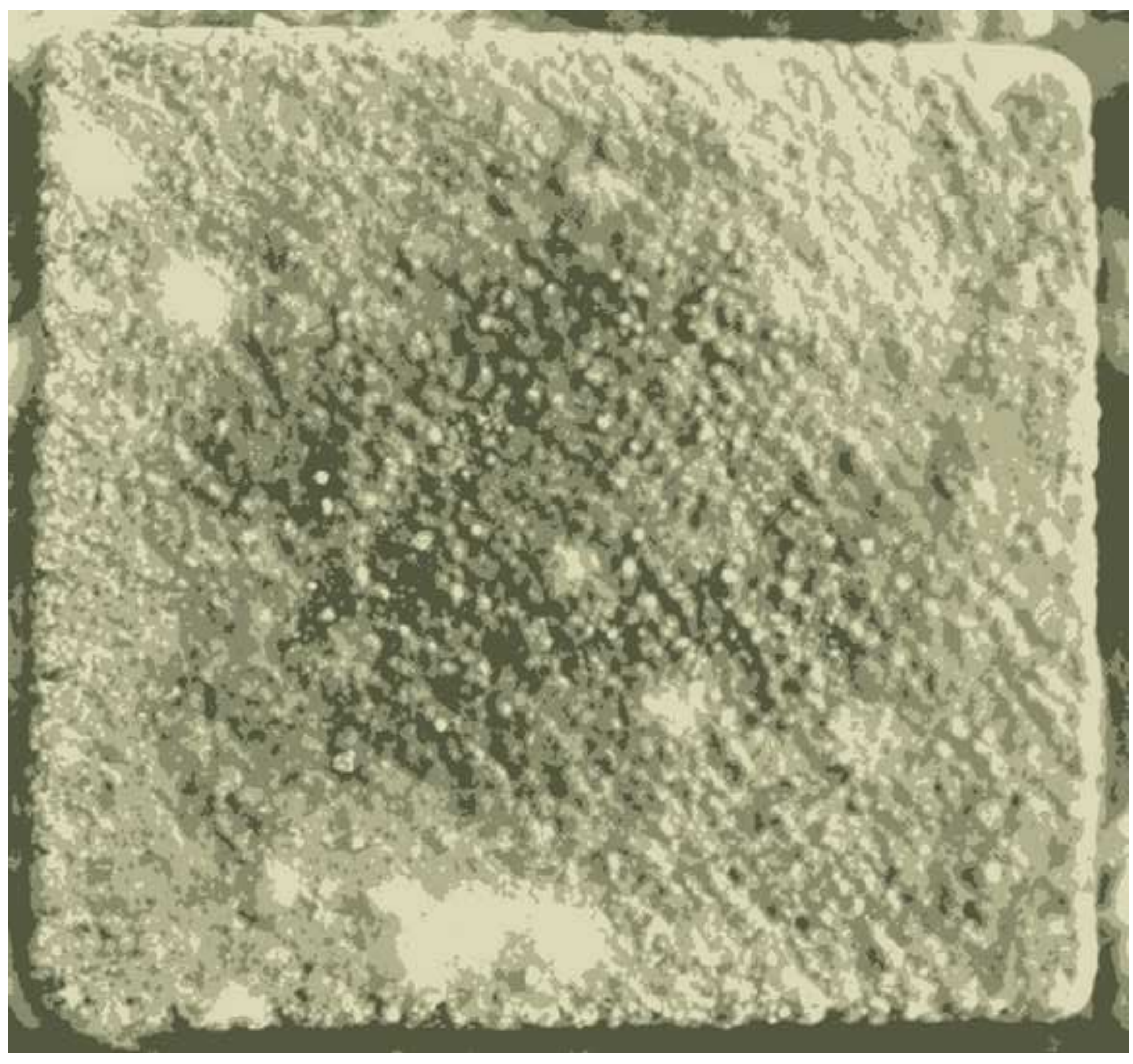

.

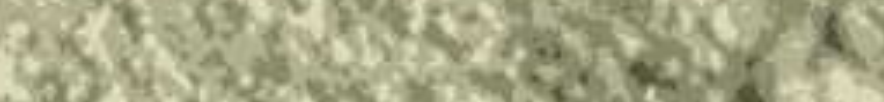

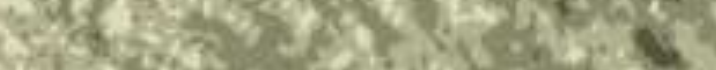
20.3

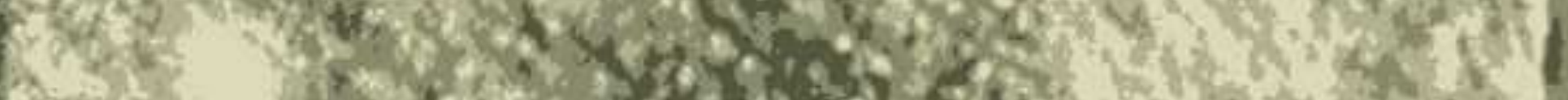

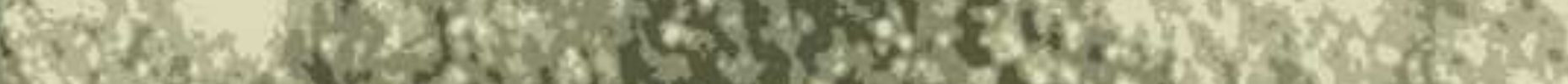
7. ${ }^{2}$.

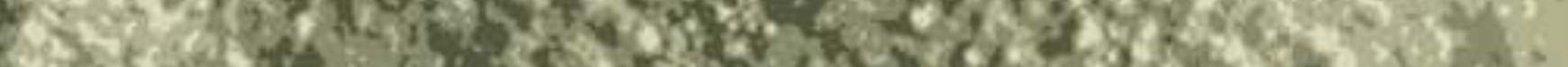
Fot 0 .

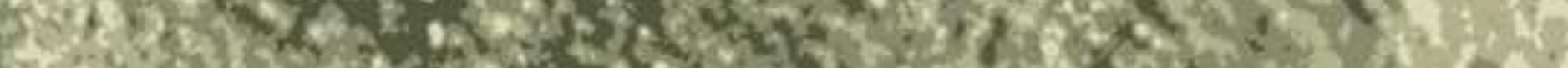

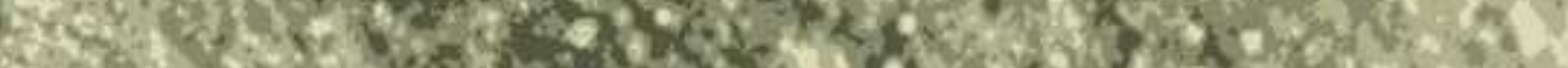

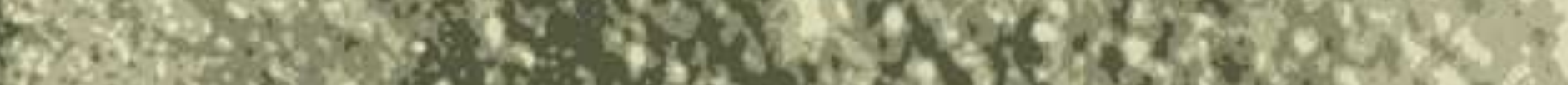

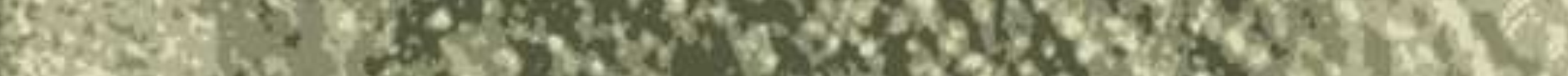

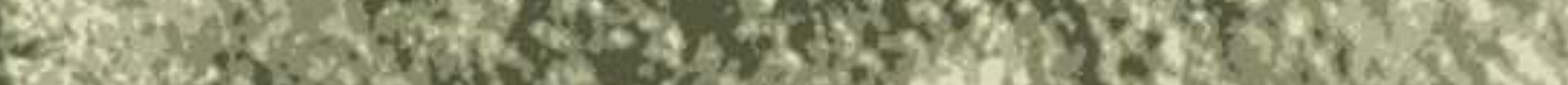

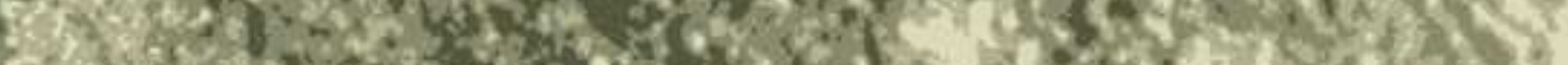

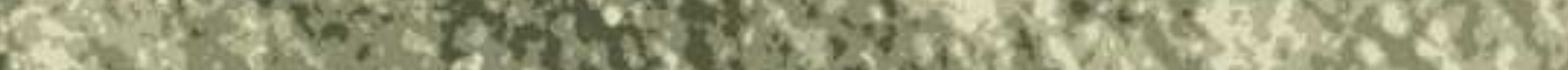
2.e.

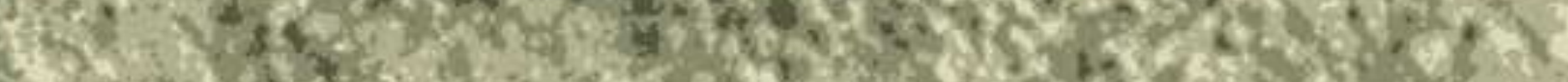

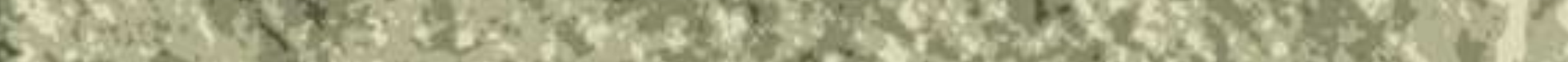

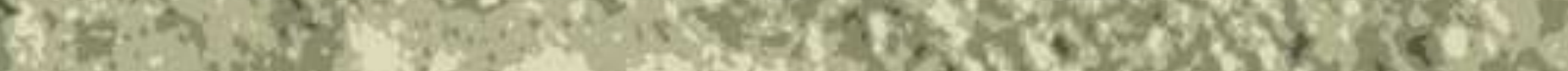

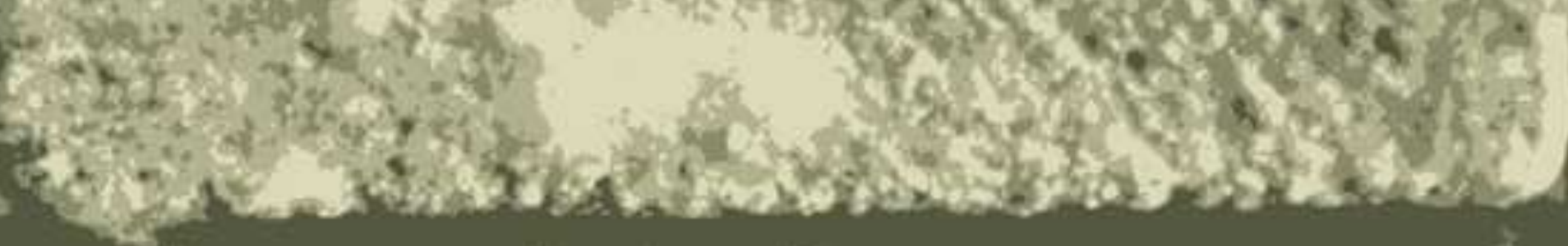
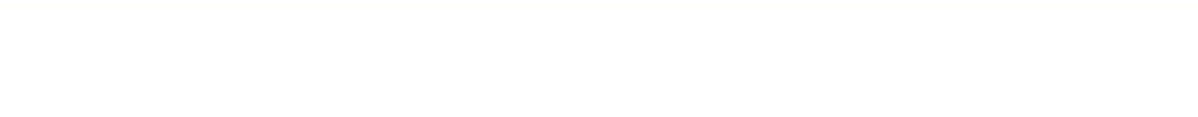
Figure

Click here to download high resolution image

A
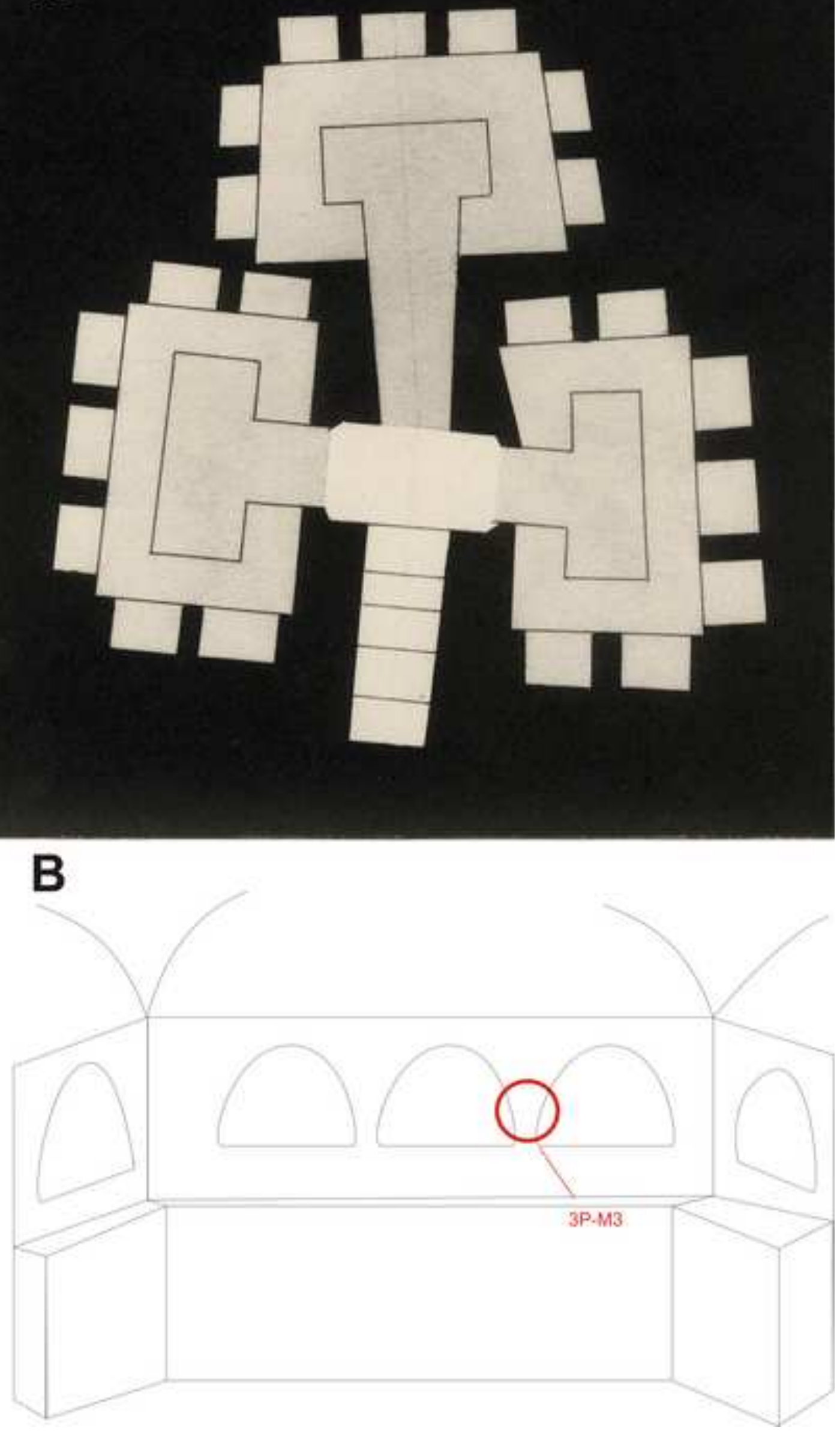
Click here to download high resolution image
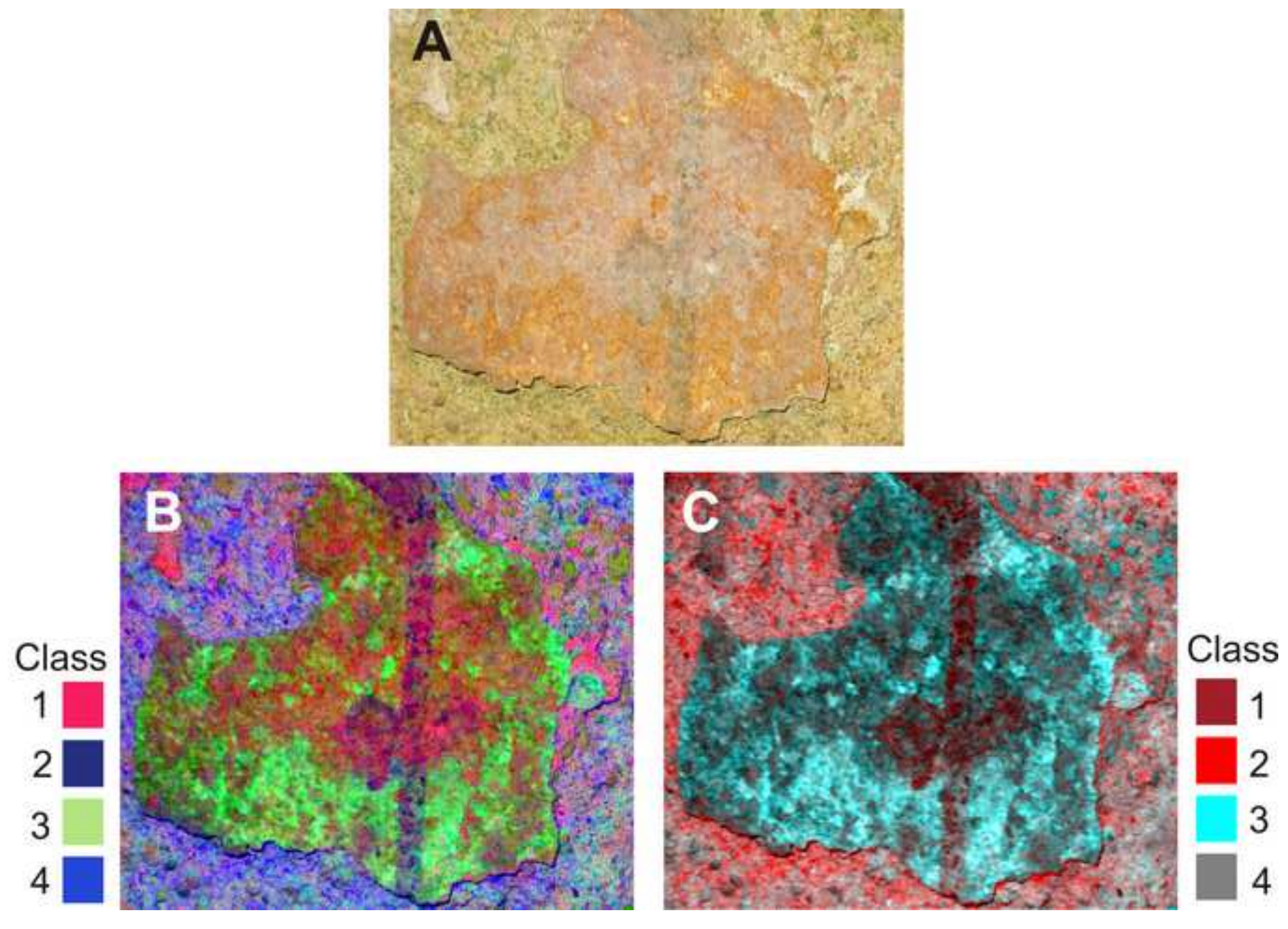

Class
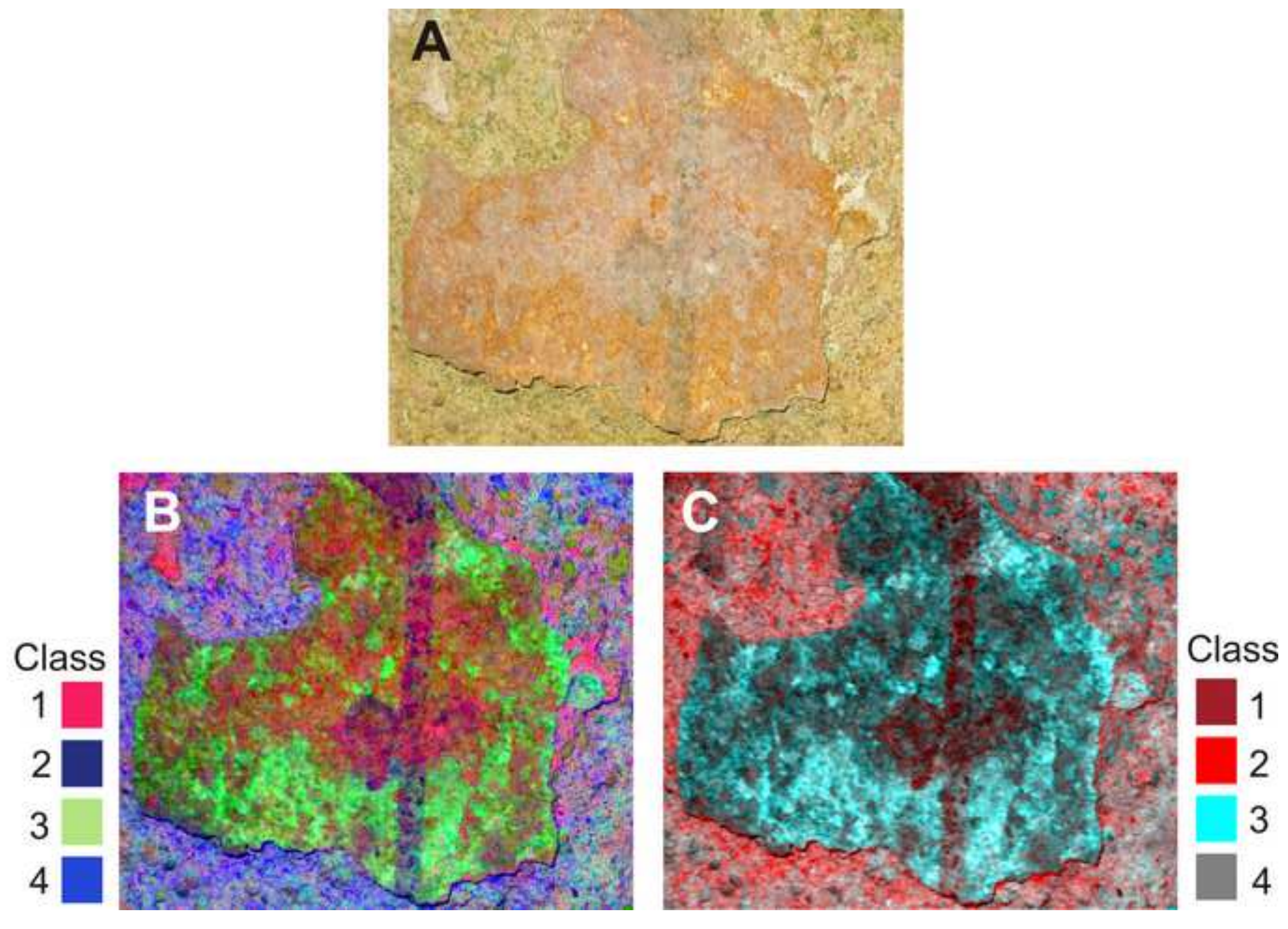

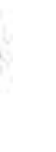

